\title{
Agronomic Characteristics, Growth Analysis, and Yield Response of Biofield Treated Mustard, Cowpea, Horse Gram, and Groundnuts
}

\author{
Mahendra Kumar Trivedi ${ }^{1}$, Alice Branton ${ }^{1}$, Dahryn Trivedi ${ }^{1}$, Gopal Nayak ${ }^{1}$, Mayank Gangwar $^{2}$, \\ Snehasis Jana ${ }^{2, *}$ \\ ${ }^{1}$ Trivedi Global Inc., Henderson, USA \\ ${ }^{2}$ Trivedi Science Research Laboratory Pvt. Ltd., Bhopal, Madhya Pradesh, India
}

Email address:

publication@trivedisrl.com (S. Jana)

\section{To cite this article:}

Mahendra Kumar Trivedi, Alice Branton, Dahryn Trivedi, Gopal Nayak, Mayank Gangwar, Snehasis Jana. Agronomic Characteristics, Growth Analysis, and Yield Response of Biofield Treated Mustard, Cowpea, Horse Gram, and Groundnuts. International Journal of Genetics and Genomics. Vol. 3, No. 6, 2015, pp. 74-80. doi: 10.11648/j.ijgg.20150306.13

\begin{abstract}
Mustard, cowpea, horse gram, and groundnuts are the seasonal pulse crops used as food and fodder in many regions of the world. In the present study, the impact of biofield energy treatment on mustard, cowpea, horse gram, and groundnuts were studied with respect to overall growth, yield, and its related yield attributes. Seeds of each crop was selected and divided in two groups, i.e. control and treated. The treated group of each seed crops was subjected to Mr. Trivedi biofield energy treatment, and were plotted in the separate fields. The plot with untreated seeds were provided with all the precautionary measures such as pesticides, fungicides and organic additives, while no such measures were taken in the plot with treated seeds. Both group of crops were further analyzed and compared for growth, yield, and yield attributes. Further, the effect of biofield treatment was also evaluated on horse gram using Random Amplified Polymorphic DNA (RAPD) analysis in order to determine their epidemiological relatedness and genetic characteristics. The results suggest that the percentage increase in yield was maximum in mustard $(500 \%)$, followed by horse gram $(105 \%)$, cow pea $(52 \%)$, and groundnut $(44 \%)$ as compared with their control. However, improved plant height, overall growth, yield of seeds, plants were free from any diseases and pest were observed in treated group as compared with its respective control. RAPD analysis using eight primers results in polymorphism and the percentage of true polymorphism observed between control and treated samples of horse gram seed sample with an average value of 53\%. The overall results suggested that Mr. Trivedi's biofield energy treatment has a significant impact on mustard, cowpea, horse gram, and groundnuts, which might be used as a better alternative approach to increase the yield of crop as compared with the synthetic chemicals.
\end{abstract}

Keywords: Biofield Energy Treatment, Mustard, Cowpea, Horse Gram, Groundnut, Polymorphism, Random Amplified Polymorphic DNA, Yield attributes

\section{Introduction}

Mustard (Brassica juncea) is one of the most important oil seed crops in all over the world, while its major consumption is in India. Due to its flexibility in different climate conditions, it was widely cultivated world-wide. Optimum agronomic traits of mustard are mostly resistance against high temperature, drought, pest and disease that made this crop compatible to different climate and geographical conditions [1]. High yield of mustard can be achieved on fertile soil with a clayloam texture. However, soil nutrition management is considered as one of the most important factor for crop breeding. Nitrogen, is still considered as the significant factor in final crop productivity in mustard. It supports the growth of plant, enhance seed and fruit yield, which improves the quality of leaf and seed oil [2].

Grain legumes being the major protein source in human and animal nutrition, and play a major role in crop rotations across the world. Crop rotation along with other crops will improve the soil fertility, and reduce weeds, pest, and diseases [3]. Cowpea (Vigna unguiculata), the major legumes in the vegetarian diet with high carbohydrate content. Cowpea is one of the drought resistant crops, and 
considered as important legume in newly cultivated land. Due to its very high protein concentration, its agronomical importance is demanding for human and animal diet as an alternative protein source. Fresh pods, leaves and the dried seeds are popularly used as an ingredients in different dishes, seeds can be cooked with meat, tomatoes, and onions. Its nutritional value is similar with other pulses, with low fat and high protein content [4].

Horse gram (Macrotyloma uniflorum) is an underutilized warm season food legume, mainly grown as pulse crop in India, while as a forage crop in semi-arid regions of the world [5]. Although, less genetic information of horse gram is available, but it was considered and has the potential as future pulse due to its high therapeutic potential. Due to its high tolerance against salinity, drought, and heavy metals [6], horse gram species possess different medicinal properties such as antimicrobial, antioxidant activity, and is also reported to be effective in kidney stones dissolution $[7,8]$. Groundnut (Arachis hypogaea L.), also known as peanut, one of the most popular oil seed in the world. The use of minerals, fertilizers, etc. must be optimized for the ground production, as it has very high nutrient requirements. However, mineral nutrient deficiency due to imbalance supply of plant fertilizers, will results in low yield, yield attributes, and ultimately overall growth of plant. Contrarily, excessive use of chemical fertilizers, pesticides, etc. in agricultural crops will sediment the harmful chemicals at every level and show cumulative effect, which ultimately affect the health of humans and animals on consumption. Because of continuous use and harmful effect of fertilizers, authors have tried to study the use of alternative sources such as biofield energy treatment on the agricultural crops with respect to its yield and related parameters.

Biofield energy treatment on agricultural crops have been recently reported to improve the yield, yield attributes, and overall growth of plants $[9,10]$. Biofield energy is one of the energy therapy used now a days in different research fields with improved and significant results world-wide. It requires a subtle or very low intensity stimuli/energy absorbed by different biomolecules, due to changes in the movements of component parts. Therefore, the human or any living object, not only radiate but also absorb and respond to these frequencies [11]. Energy medicines have been classified by National Center for Complementary and Alternative Medicine (NCCAM) as one of the alternative approach of treatment [12]. Mr. Mahendra Kumar Trivedi possess unique biofield energy, which has the ability to alter the characteristics of living and non-living things. Mr. Trivedi's unique biofield treatment is also termed as The Trivedi Effect $^{\circledR}$, which has been studied in the field of agricultural science research [13], and biotechnology [14]. After considering the significant effects of biofield treatment, and low productivity of agricultural crops, present study evaluates the impact of The Trivedi Effect ${ }^{\circledR}$ on mustard, cowpea, horse gram, and groundnuts with respect to their growth, yield, and other related growth parameters.

\section{Materials and Methods}

\subsection{Plant Materials}

Plants such as mustard, cowpea (Konkan safed), horse gram, and groundnut ( 2 varieties viz. Konkan Gaurav and Konkan Tapora) were selected for the study. The seeds and plants were collected before and after the treatment and analyzed in the Department of Botany, research farm of Dr. B.S. Konkan Krishi Vidyapeeth, Dapoli, Maharashtra, India. Experimental analysis (Grain/seed yield) was performed in two plots, which were approximately 15 feet away from each other with the same environmental and soil conditions. One plot was used as control (untreated seeds), where all the measures were provided to seeds and plants such as pesticides, fungicides and organic additives. The other plot was defined as treated, where biofield treated seeds were grown in similar environmental and soil conditions without any precautionary measures, as given in the plot grown with untreated seeds [15].

\subsection{Biofield Treatment Modalities}

Control plot was cultivated with normal untreated seeds of mustard, cowpea, horse gram, and groundnuts as per standard procedure. The other plot defined as treated plot was chosen for evaluating the impact of Mr. Trivedi' biofield energy treatment (The Trivedi Effect ${ }^{\mathbb{B}}$ ) on selected seeds after biofield treatment as compared to the untreated seeds. Mr. Trivedi provided the biofield treatment through his energy transmission process, which includes bioenergy emission to the seeds without touching them. After treatment, the seed samples were returned in the same condition and stored for cultivation as per the standard procedure. The differences in seeds and plants parameters in control and treated seeds were noted and compared [15].

\subsection{Growth, Yield, and Yield Attributes of Crops}

Biofield treated seeds were allowed to germinate until ready to be transplanted according to the season. As a control, untreated seeds were allowed to germinate in the same manner and transplanted alongside in the treated plots in a randomized fashion. Overall plant height, primary and secondary branches, seed/grain yield, and harvest index of the control and treated crops were calculated [15].

\subsection{Isolation of Plant Genomic DNA}

After germination when the plant (horse gram) reached an appropriate stage, leaves disc were harvested from each control and treated plants. Genomic DNA of germinated seeds (leaves disc) were isolated according to standard cetyltrimethyl ammonium bromide (CTAB) method [16]. For DNA isolation, control and treated group of seeds were stored at $-40^{\circ} \mathrm{C}$. DNA was extracted as per the standard protocol of CTAB method, which involve the use of approximately $10 \mathrm{mg}$ of seed material followed by grinding it into a fine paste. The quantification of DNA was done by $0.8 \%$ agarose gel electrophoresis, which confirm the DNA quality. The presence of a highly resolved high molecular weight band indicates 
good quality DNA, while presence of a smeared band indicates degraded DNA. The extracted DNA was kept at $4^{\circ} \mathrm{C}$ until further use.

\subsection{Random Amplified Polymorphic DNA (RAPD) Analysis}

RAPD technique was used for fingerprinting the DNA of control and treated sample of horse gram. The RAPD reactions using eight RAPD primers (RPL series used separately viz. RPL 11A, RPL 13A, RPL 16A, RPL 18A, RPL 19A and RPL 20A, RPL4A, and DF10) was performed to find the polymorphism between control and treated seeds under PCR conditions as mentioned. Amplifications were performed with denaturation at $94^{\circ} \mathrm{C}$ for $5 \mathrm{~min}$, followed by 40 cycles annealing at $94^{\circ} \mathrm{C}$ for $1 \mathrm{~min}$, annealing at $36^{\circ} \mathrm{C}$ for $1 \mathrm{~min}$ and extension at $72^{\circ} \mathrm{C}$ for $2 \mathrm{~min}$. The final extension cycle was carried out at $72^{\circ} \mathrm{C}$ for $10 \mathrm{~min}$. The PCR reaction mixture (12 $\mu \mathrm{L})$ of control and treated groups of DNA template were visualized on $1.5 \%$ agarose gel and size of each fragment was estimated using 100 bp Ladder $\left(\mathrm{Genei}^{\mathrm{TM}}\right)$. For clear visualization of bands ethidium bromide dye $(1.5 \mu \mathrm{L}$ of 0.5 $\mu \mathrm{g} / \mathrm{mL}$ final concentration) was added and gel images were processed in gel documentation system [17].

The percentage of polymorphism was calculated using following equation:

\section{Percent polymorphism $=\mathrm{A} / \mathrm{B} \times 100$;}

Where, $\mathrm{A}=$ number of polymorphic bands in treated sample; and $\mathrm{B}=$ number of polymorphic bands in control.

\section{Results and Discussion}

\subsection{Effect on Growth, Yield, and Yield Attributes of Mustard}

Effect of biofield treatment and its related data were presented in Table 1, which revealed marked difference in plant height of treated mustard at maturity as compared with the control. Plants obtained from the treated seeds and plot grew taller and were recorded $53.68 \%$ higher plant height than the control plants. Primary branching in the treated plots were improved by $190.48 \%$, while significant increase was reported by $357.57 \%$ in secondary branches as compared with the control. Untreated mustard crop showed high rate of infection by pests and disease, and leaves showed survival rate hardly by $40 \%$, while biofield treated mustard was free from any kind of disease or pest attack, and leaves were quite thick, large, dark green in color, and more secondary and tertiary branches (Figure 1). Among the yield attributing characters, significantly high number of siliquae on main shoot, siliquae/plant, and siliqua length were observed in the treated seeds and plot as compared with the control (Table 1). Seed and stover yield of mustard in the treated plots were increased by $500 \%$ and $275 \%$, respectively with respect to the control. After biofield treatment, chlorophyll a and $\mathrm{b}$ content in leaf were significantly increased as $30.18 \%$ and $96.72 \%$ respectively. However, grain/seed yield of mustard crop after biofield treatment was increased by $500 \%$ in terms of $\mathrm{kg}$ per meter square (Table 2 and Figure 4). Use of fertilizers, pesticides, and nutrient management have been well reported as they plays a key role in increasing and stabilizing the productivity of mustard [18]. Study results suggest, that biofield treatment could be a new and safe approach in term of growth and yield of mustard crop.
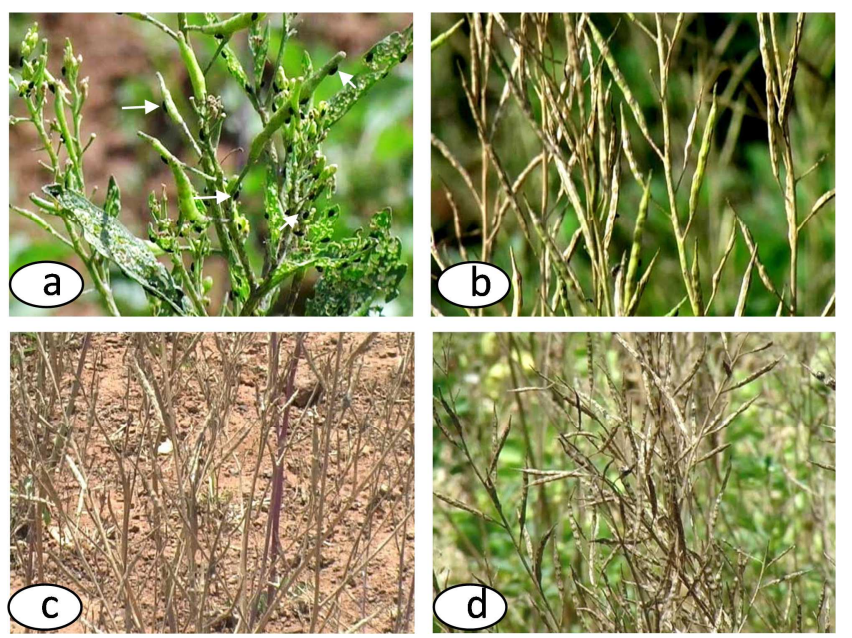

Figure 1. Effect of biofield treatment on mustard crop (a) control crops marked with high infection by pests and disease (b) biofield treated free from any kind of disease or pest attack, (c) control leaves survival rate was hardly $40 \%$ with slow growth, (d) biofield treated leaves were quite thick, large, dark green in color, and more secondary and tertiary branches.

Table 1. Growth, yield attributes and yield of control and biofield treated mustard.

\begin{tabular}{|c|c|c|c|c|c|c|c|c|c|c|c|}
\hline \multirow{3}{*}{ Group } & \multirow{3}{*}{$\begin{array}{l}\text { Plant } \\
\text { Height } \\
(\mathrm{cm})\end{array}$} & \multicolumn{2}{|c|}{ Branches per Plant } & \multicolumn{2}{|c|}{ Siliquae per Plant } & \multirow{3}{*}{ Siliqua length $(\mathrm{cm})$} & \multirow{3}{*}{$\begin{array}{l}\text { Weight (g) of } \\
1000 \text { Seeds }\end{array}$} & \multirow{3}{*}{$\begin{array}{l}\text { Seed Yield } \\
\text { quintal } \\
\text { /hectare }\end{array}$} & \multirow{3}{*}{$\begin{array}{l}\text { Stover } \\
\text { Yield } \\
\text { quintal/ha }\end{array}$} & \multirow{2}{*}{\multicolumn{2}{|c|}{$\begin{array}{l}\text { Chlorophyll in } \\
\text { Leaf (mg/g) }\end{array}$}} \\
\hline & & Pri & Se & & Tat. & & & & & & \\
\hline & & Pri. & Sec. & Main Shoot & Total & & & & & Chl.a & Chl.b \\
\hline Control & 95.0 & 2.1 & 3.3 & 5.7 & 67.0 & 3.2 & 4.8 & 2.0 & 9.6 & 0.742 & 0.244 \\
\hline Treated & 146.0 & 6.1 & 15.1 & 27.9 & 189.0 & 5.32 & 5.48 & 12.0 & 36.0 & 0.966 & 0.480 \\
\hline
\end{tabular}

Chl. a, b: Chlorophyll a and b; Pri: Primary; Sec: Secondary

\subsection{Growth and Grain/Seed Yield of Cowpea, Horse Gram, and Groundnut}

The control and biofield treated seeds were grown and analyzed for the differences in growth and yield of plant. Biofield treated seeds showed immediate germination in all the treated groups of seeds within first 5-6 days as compared to the 10-15 days in control group. Further, after 18 to 25 days, the seeds which were deeply placed in the soil, had also germinated by lifting up the soil, while the control group does not show any germination in this situation. Generally, the deep-seated seeds fail to germinate due to unavailability of the sufficient energy. But the biofield treated seeds do germinate even in deep-seated state, where solar energy exist in less 
amount, that means there is another type of energy provided to the seeds for germination. Biofield energy treatment might have helped the seeds during the germination of the deep-seated treated seeds and gives rise to enhanced germination and survival rate.

All the biofield treated crops showed dark green colored leaves with a thick consistency and being more in numbers, as compared with the control crops. Similarly, biofield treated cowpea and horse gram showed high survival rate after germination, free from any kind of infections, and canopy of plants were better as compared with the control. Overall, the treated crop of cowpea and horse gram showed high yield as compared with the control. Both showed high survival rate with early germination and free from pest and disease. Further leaves of treated plants showed more pods per plant, with bright green color as compared with the control cowpea and horse gram crops (Figure 2 and 3). Moreover, crops from all the treated seeds were found with very thick population and free from the diseases and pests attack as compared with the respective control. In biofield treated seeds, there was no airborne infection observed which defies the laws of aerobiology. On contrary, the control crops were found to grown very close to each other and were found to be infected with diseases and pests attacks.

Table 2. Effect of biofield treatment on the grain/seed yield of mustard, cow pea, horse gram, and groundnut.

\begin{tabular}{lll}
\hline \multirow{2}{*}{ Name of the crop } & \multicolumn{2}{l}{ Grain/seed yield } \\
\cline { 2 - 3 } & Control & Treated \\
\hline Mustard $\mathrm{kg} / \mathrm{sq} \mathrm{mts}$ & 0.002 & 0.012 \\
Cow pea (Konkan Safed) $\mathrm{kg} / \mathrm{sq} \mathrm{mts}$ & 0.044 & 0.067 \\
Horse gram $\mathrm{kg} / \mathrm{sq} \mathrm{mts}$ & 0.037 & 0.076 \\
Groundnut-(Konkan Gaurav) $\mathrm{kg} / 2 \times 2 \mathrm{mts}$ & 1.500 & 1.700 \\
Groundnut- (Konkan Tapora) $\mathrm{kg} / 2 \times 2 \mathrm{mts}$ & 1.800 & 2.600 \\
\hline
\end{tabular}

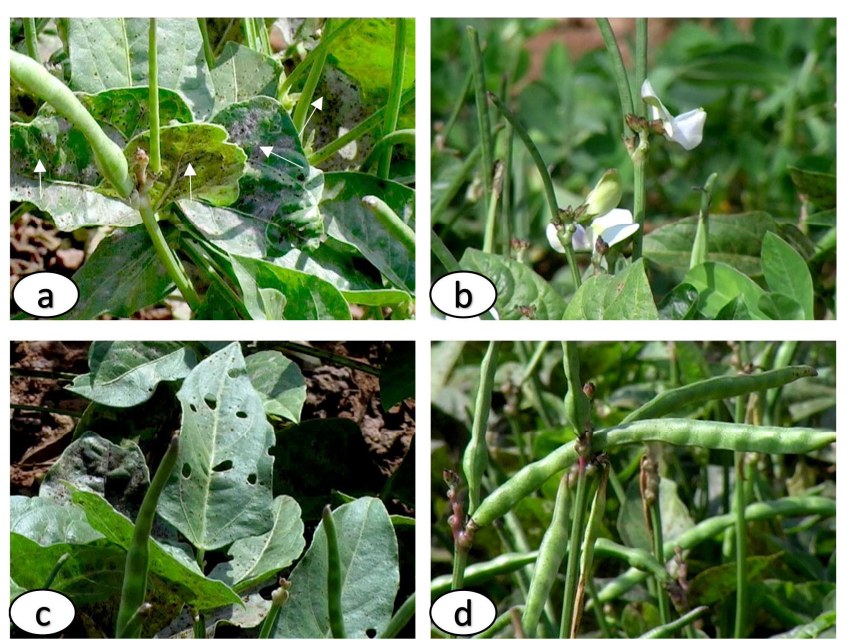

Figure 2. Effect of biofield energy treatment on cowpea (a) control plants germinated in 10-15 days with 60-65\% survival rate, and leaves of the plant were highly infected (b) biofield treated seeds germinated in 5-6 days with 99\% survival rate and free from any kind of disease or pest attack, (c) control plants showed fewer pods per plant, results in less yield, (d) biofield treated seeds pods were quite large and all of the pods were filled with grains, high yield.

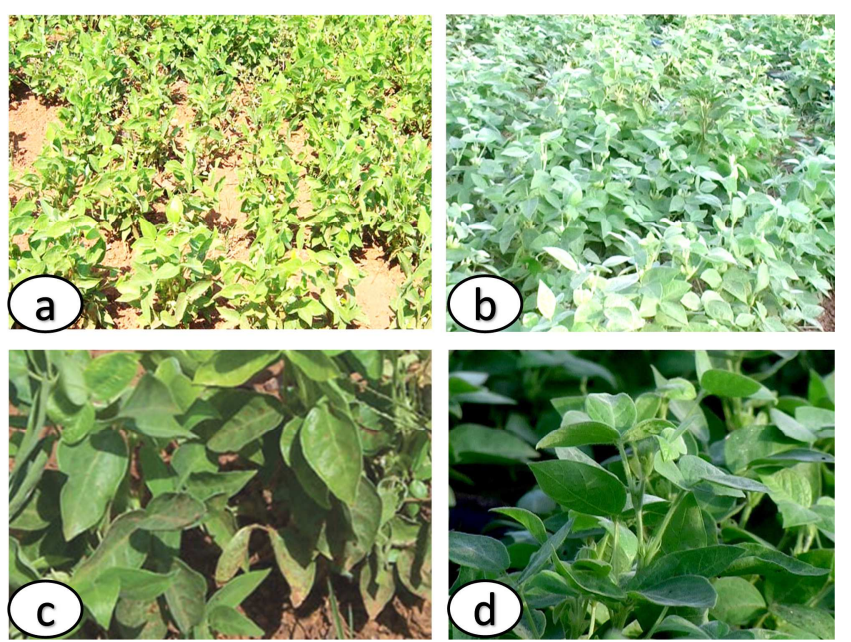

Figure 3. Effect of biofield energy treatment on horse gram (a) control plants germinates slow with less survival rate, and population of the plants was not dense (b) biofield treated seeds showed dense population with health crops, (c) control plants showed pale green leaves, and canopy was small with less number of leaves (d) biofield treated leaves were bright green and glossy, with more pods per plant.

The canopy of the plants will affect the crop yield due to variation in light, environment, which depends on the phytochromes, cryptochromes, phototropins, and the photoreceptor of the plants [19]. Canopy of the biofield energy treated trees were more than the double compared to the control ones having more secondary and tertiary branches. Leaf area and its duration were considerable high in treated crops, which are revealed by more grain/seed yields. Leaf area duration is directly related with the final productivity of the crop [20]. Out of cowpea, horse gram, and groundnuts crop varieties, maximum percentage increase in yield was reported in case of horse gram (105\%), followed by cow pea (52\%), and groundnut (13 and 44\%) as compared with their control yield (Table 2 and Figure 4). All the yield contributing characters were increased in treated plants as compared to the control. Therefore, the total yield of all the biofield treated crops were increased as compared with the control.

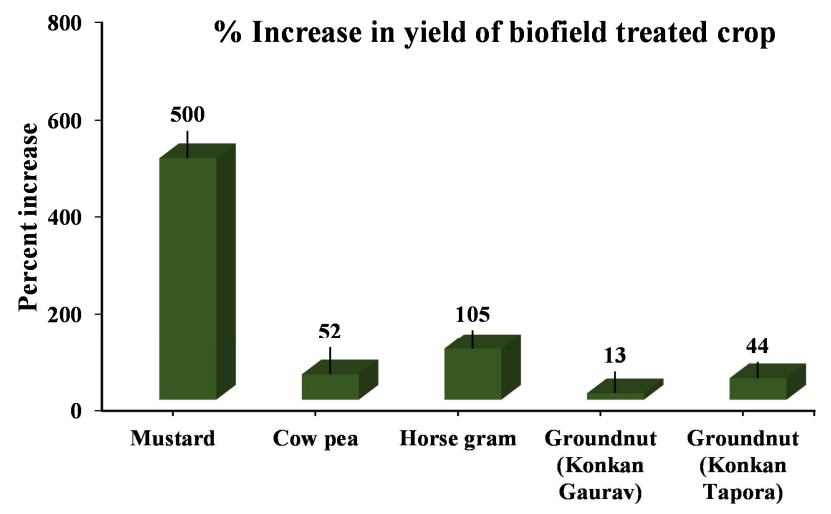

Figure 4. Effect of biofield energy treatment on percent increase in grain/seed yield crop of mustard, cowpea, horse gram, and groundnut.

The leaves of all the treated crops were remained dark green and glossy untill the harvesting period with a very low rate of senescence, which indicates that they were photo synthetically 
active till the end. The treated crops draw energy till the last phase of life cycle attributing more final yields. In the treated crops, the flowering was started 30 days early as compared to the control plot suggestive of early maturity and acceleration of growth. The longevity of the all crops in the treated plot was found to be increased hence fruiting period has also been extended resulting in higher yield. It was observed that in the treated plot there was no weeds or unwanted plant growth, whereas in the control plot even after spraying weedicides (three times) the weeds was continuously required to be removed approximately four times manually. It was reported that climatic change can influences the flowering time, and overall productivity of crops [21], but biofield treated crops were reported with better flowering and growth, which was directly related to overall productivity.

Another important factor observed was that the soil from the treated plot was also transformed after biofield treatment. It was found that the percentage of pathogens \& fungus was decreased, while the supportive bacteria's which helps the soil for nitrogen fixing, decomposing soil, making nutrient readily available for the plants to absorb more nutrients were substantially increased by multiple folds after treatment. Seeds harvested were larger in size and free from all diseases and pests and they had matured early ranging from 8 to 12 days compared to the control ones. In case of treated cowpea, harvesting was done only once, while in the control plot harvesting had to be completed in two times, which is one of the remarkable features in term of yield. The uniform maturity in case of pulse crop was generally not observed, but in case of biofield treatment the uniformed maturity of the crop was noticed, which was useful for increasing the yield of pulse crop.

\subsection{DNA Fingerprinting of Biofield Treated Horse Gram by RAPD Analysis}

Biofield energy treatment on horse gram was given to determine the epidemiological relatedness and genetic characteristics of control and treated group. RAPD analysis was performed to study the correlation based on genetic similarity or mutations between the biofield treated and the control sample. RAPD analysis basically required a short nucleotide primers, which were unrelated to known DNA sequences of the target genome. DNA polymorphism can be efficiently detected using PCR primers and identify inter-strain variations among plant species in treated samples. The degree of relatedness and genetic mapping can be correlated between similar or different treated sample [22].

Random amplified polymorphic-DNA fragment patterns of control and treated horse gram samples were generated using eight RAPD primers, using 100 base pair DNA ladder, while results are presented in Figure 5. The DNA profiles of treated group were compared with their respective control. The polymorphic bands observed using eight different primers in control and treated samples were marked by arrows. The RAPD patterns of treated samples showed some unique and dissimilar bands using eight primers. DNA polymorphism analyzed by RAPD analysis, the total number of bands, common, and unique bands are summarized in Table 3. The level of polymorphism in terms of percentage values between control and treated sample were varied as shown in Figure 5. The level of polymorphism using eight primers were ranged from 25 to $90 \%$ between control and treated sample after the biofield treatment. However, level of polymorphism between control and treated group using RPL 11A, RPL 13A, RPL 16A, RPL 18A, RPL 19A, RPL 20A, RPL4A, and DF10 was found to be $72,26,72,90$, and $25 \%$, respectively. The highest change in DNA sequence was observed in treated group with RPL 19A primer as compared to control; however minimum polymorphism was found in treated group with RPL 20A primer as compared to the control. RAPD also explain the relevant degree of genetic diversity. However, this technique has the potential to detect polymorphism throughout the entire genome.

Table 3. DNA polymorphism of horse gram analyzed after biofield treatment using random amplified polymorphic DNA (RAPD) analysis.

\begin{tabular}{lllllll}
\hline \multirow{2}{*}{ S. No. } & Primer & $\begin{array}{l}\text { Band } \\
\text { Scored }\end{array}$ & $\begin{array}{l}\text { Common bands in } \\
\text { control and treated }\end{array}$ & \multicolumn{2}{c}{ Unique band } \\
\cline { 5 - 6 } & & - & - & - & - \\
RPL 11A & - & 10 & 5 & 12 \\
RPL 13A & 11 & 14 & 2 & 2 \\
RPL 16A & 15 & 11 & 5 & 3 \\
RPL 18A & 11 & 8 & 4 & 5 \\
RPL 19A & 10 & 5 & 1 & 1 \\
RPL 20A & 8 & 6 & 3 & 6 \\
RPL4A & 8 & 8 & 1 & 2 \\
DF10 & 10 & 8 & & Treated \\
\hline
\end{tabular}

RPL11A RPL13A RPL16A RPL18A RPL19A RPL20A RPL4A DF10

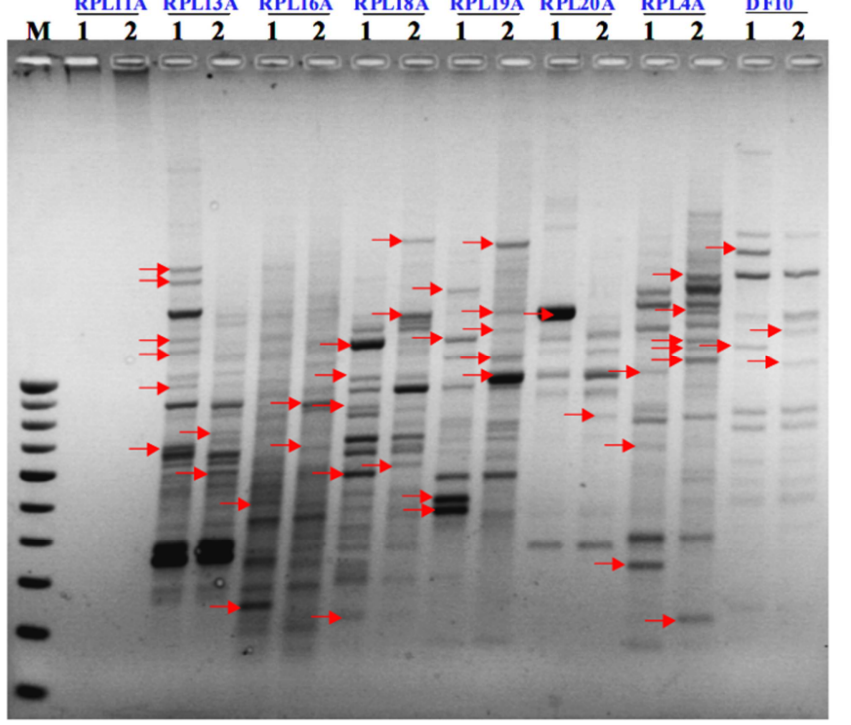

Figure 5. Random amplified polymorphic-DNA fragment patterns of biofield treated horse gram generated using eight RAPD primers, RPL 11A, RPL 13A, RPL 16A, RPL 18A, RPL 19A \& RPL 20A, RPL4A, and DF10. M: $100 \mathrm{bp} D N A$ Ladder; Lane 1: Control; Lane 2: Treated.

High level of phenotypic plasticity was reported in plants as compared to the larger animals in response to different environmental conditions, which supports its capacity for quicker change in DNA as adaptive responses. Besides, the adaptive changes were easily reflected, such as visible morphological characters, and possibility of genetic 
alterations. If genetic processes of plants can be influenced by the impact of biofield energy, this could be better used to alter the yield, productivity, overall health, etc. of the treated crops. High level of genetic diversity has been reported in horse gram using various RAPD primers [23]. However, biofield treatment has been reported with improved overall plant health of Withania somnifera and Amaranthus dubius. Leaf, stem, flower, seed setting, and immunity parameters were reported to be improved after biofield treatment. Concentrations of chlorophyll $\mathrm{a}$, chlorophyll $\mathrm{b}$ and total chlorophyll were consistently higher in treated plants along with genetic variability using RAPD DNA fingerprinting [14]. The impact of biofield treatment on yield of ginseng, blueberry [9], and growth and yield of lettuce and tomato were reported [13]. Similar results were observed in our experiment with biofield treated mustard, cowpea, horse gram, and groundnuts. Results are well supported with existing literature in terms of growth, yield, and genetic variability of crops.

The improved yield and consistency of results across multiple kinds of crop samples suggested the efficacy of biofield energy treatment on plants. The results suggest that biofield energy may interact sufficiently with plants genetic materials, which stands the crop in disease free environment, improved color in plant, and are able to produce healthier plants with higher yield.

\section{Conclusions}

In conclusion, biofield treatment on agricultural crops showed an improved overall yield of the treated crops as compared to the control. The percentage increase in yield was maximum in case of mustard (500\%), followed by horse gram (105\%), cowpea (52\%), and groundnut (44\%). Mustard was reported with significant increase in chlorophyll content approximately by 30 to $96 \%$ as compared with the control crops. Linear growth, plant height, branches, and grain/seed yield were found increased in all the biofield treated crops, without any precautionary measures such as pesticides, fungicides, and organic additives. Canopy and leaf area duration of the biofield energy treated crops were more than double compared to the control ones having more secondary and tertiary branches. RAPD analysis using eight primers showed 25 to $90 \%$ polymorphism in control and biofield treated horse gram with more unique bands in treated as compared with the control, which might be to the presence of high degree of phenotypic plasticity. Overall, Mr. Trivedi's biofield energy treatment results an improved yield in multiple kinds of crops, suggests the significant application of biofield treatment in agriculture sector instead of chemical measures to improve the overall productivity.

\section{Acknowledgements}

Authors are thankful to the support of Trivedi Science ${ }^{\mathrm{TM}}$, Trivedi Master Wellness ${ }^{\mathrm{TM}}$ and Trivedi Testimonials in this research work. Authors acknowledge the generosity to Bangalore Genei Private Limited, for conducting RAPD analysis.

\section{References}

[1] Wysocki D, Corp M (2002) Edible mustard. Oregon State Univ. EM 8796-E.

[2] Allen EJ, Morgan DG (1972) A quantitative analysis of the effects of nitrogen on the growth, development and yield of oilseed rape. J Agri Sci 78: 315-324.

[3] Chemining wa GN, Vessey JK (2006) The abundance and efficacy of Rhizobium leguminosarum bv. viciae in cultivated soils of the eastern Canadian prairie. Soil Biol Biochem 38: 294-302.

[4] Timko MP, Singh BB (2008) Cowpea, a multi-functional legume. Genomics of Tropical Crop Plants, (1stedn). Springer science + Business media LLC, New York.

[5] Jansen PCM (1989) Macrotyloma uniflorum (lam) Verdc. Plant resources of South East Asia, pulses. Pudoc, Wagenin.

[6] Reddy PCO, Sairanganayakulu G, Thippeswamy M, Reddy PS, Reddy MK, et al. (2008) Identification of stress-induced genes from the drought tolerant semi-arid legume crop horsegram (Macrotyloma uniflorum (Lam.) Verdc.) through analysis of subtracted expressed sequence tags. Plant Sci 175: 372-384.

[7] Kawsar SMA, Serajuddin M, Huq E, Nahar N, Ozeki Y (2008) Biological investigation of Macrotyloma uniflorum Linn. extracts against some pathogens. J Biol Sci 8: 1051-1056.

[8] Reddy AM, Kumar SG, Jyothsnakumari G, Thimmanaik S, Sudhakar C (2005) Lead induced changes in antioxidant metabolism of horsegram (Macrotyloma uniflorum (Lam.) Verdc.) and Bengal gram (Cicer arietinum L.). Chemosphere 60: 97-104.

[9] Sances F, Flora E, Patil S, Spence A, Shinde V (2013) Impact of biofield treatment on ginseng and organic blueberry yield. AGRIVITA J Agri Sci 35: 22-29.

[10] Lenssen AW (2013) Biofield and fungicide seed treatment influences on soybean productivity, seed quality and weed community. Agricultural Journal 8: 138-143.

[11] Oschman JL (2000) Energy medicine: The scientific base. (2ndedn), Edinburgh: Churchill Livingston.

[12] NIH, National Center for Complementary and Alternative Medicine. CAM Basics. Publication 347. [October 2, 2008]. Available at: http://nccam.nih.gov/health/whatiscam/

[13] Shinde V, Sances F, Patil S, Spence A (2012) Impact of biofield treatment on growth and yield of lettuce and tomato. Aust $\mathrm{J}$ Basic Appl Sci 6: 100-105.

[14] Nayak G, Altekar N (2015) Effect of biofield treatment on plant growth and adaptation. J Environ Health Sci 1: 1-9.

[15] Patil SA, Nayak GB, Barve SS, Tembe RP, Khan RR (2012) Impact of biofield treatment on growth and anatomical characteristics of Pogostemon cablin (Benth.). Biotechnology 11: 154-162.

[16] Sambrook J, Fritsch EF, Maniatis T (2000) Molecular Cloning: A Laboratory Manual. (2nd edn), Cold spring harbor: Cold spring harbor laboratory Press.

[17] Semagn K, Bjornstad A, Ndjiondjop MN (2006) An overview of molecular marker methods for plants. Afr J Biotechnol 5: 2540-2568. 
[18] Shekhawat K, Rathore SS, Premi OP, Kandpal BK, Chauhan JS (2012) Advances in agronomic management of Indian mustard (Brassica juncea (L.) Czernj. Cosson): An overview. Int J Agron 2012: 14. Article ID 408284.

[19] Casal JJ (2013) Canopy light signals and crop yield in sickness and in health. ISRN Agronomy 2013: 16. Article ID 650439.

[20] Devendra R, Urs YSV, Kumar MU, Sastry KSK (1983) Leaf area duration and its relationship to productivity in early cultivars of rice. Proc Natl Acad Sci USA B49: 692-696.
[21] Craufurd PQ, Wheeler TR (2009) Climate change and the flowering time of annual crops. J Exp Bot 60: 2529-2539.

[22] Nybom H, Weising K, Rotter B (2014) DNA fingerprinting in botany: Past, present, future. Investig Genet 5: 1.

[23] Sharma V, Sharma TR, Rana JC, Chahota RK (2015) Analysis of genetic diversity and population structure in horsegram (Macrotyloma uniflorum) using RAPD and ISSR markers. Agric Res 4: 221-230. 